\title{
Perlindungan Hukum Terhadap Intervensi Pemberitaan dalam Kerangka Kemerdekaan Pers Nasional
}

\author{
Fuqoha $^{1}$, Indrianti Azhar Firdausi², Arga Eka Sanjaya ${ }^{3}$ \\ Fakultas Ilmu Sosial, Politik dan Hukum, Universitas Serang Raya, Serang. \\ Email : 1fuqoha23@gmail.com, 2indriantiazhar@gmail.com, ${ }^{3}$ nonume.ex@gmail.com.
}

Info Artikel:

| Diterima: 15 Mei 2019

| Disetujui: 28 Juni 2019

| Dipublikasikan: 02 Juli 2019

\begin{abstract}
Law protection for journalists has been guaranteed through legislation as outlined in law number 40 of 1999 concerning the press. Through the press law, the independence of the national press is a priority as a form of protection in the world of the press. In order to safeguard the independence of the national press, an independent body was formed which took care of and supervised the national press, the press council. Among the duties and functions of the press council is to enforce journalistic ethics through a journalistic code of ethics as a guide for journalists both journalists and press companies. The dynamics that occur, violations of the journalistic code of ethics sometimes create clashes with the public or the community who feel disadvantaged which results in conflict with the law. This research is a descriptive qualitative study with a normative juridical approach. From the analysis of this study shows that legal protection against violations of the journalistic code of ethics and the independence of the national press is adjusted to the main laws of the press against the intervention of parties who feel disadvantaged. The independence of the national press is directed at independence and without intervention in a story.
\end{abstract}

Keywords: legal protection, press freedom, intervention.

\begin{abstract}
Abstrak
Perlindungan hukum bagi pelaku jurnalistik telah dijamin melalui peraturan perundang-undangan yang dituangkan dalam Undang-Undang Nomor 40 Tahun 1999 Tentang Pers. Melalui Undang-Undang Pers tersebut, kemerdekaan pers nasional menjadi prioritas sebagai bentuk perlindungan dalam dunia pers. Dalam rangka menjaga kemerdekaan pers nasional, terbentuklan badan independen yang mengurusi dan mengawasi pers nasional yaitu Dewan Pers. Diantara tugas dan fungsi Dewan Pers yaitu menegakkan etika jurnalistik melalui kode etik jurnalistik sebagai pedoman bagi pelaku jurnalistik baik wartawan maupun perusahaan pers. Dinamika yang terjadi, pelanggaran kode etik jurnalistik terkadang menciptakan benturan dengan publik atau masyarakat yang merasa dirugikan yang menimbulkan pertentangan dengan undang-undang. Penelitian ini merupakan penelitian deskriptif kualitatif dengan pendekatan yuridis normatif. Dari analisis penelitian ini menunjukan bahwa perlindungan hukum terhadap pelanggaran kode etik jurnalistik dan kemerdekaan pers nasional disesuaikan dengan Undang-Undang Pokok Pers terhadap intervensi dari pihakpihak yang merasa dirugikan. Kemerdekaan pers nasional diarahkan pada kemandirian dan tanpa intervensi terhadap suatu pemeberitaan.
\end{abstract}

Kata kunci : Perlindungan Hukum, Kemerdekaan Pers, Intervensi. 


\section{A. PENDAHULUAN}

Dinamika dalam menghimpun berita dan komunikasi masa yang diselenggarakan oleh dunia pers memasuki fase baru pasca reformasi yang terjadi di Indonesia. Melalui pengesahan undang-undang No. 40 Tahun 1999 Tentang Pers membawa angin perubahan kepada pers di Indonesia. Pers Indonesia yang sebelumnya dibatasi dan diawasi secara ketat oleh pemerintah pada Era Orde Baru akhirnya bisa bernafas lega dengan datangnya kebebasan berpendapat yang diatur oleh undang-undang tersebut. Lahirnya Undang-undang No. 40 Tahun 1999 Tentang Pers sendiri didasari oleh keinginan agar pers di Indonesia dapat berkembang dengan lebih baik, demokratis, dan kredibel karena tidak berpihak pada kelompok tertentu, termasuk pemerintah, atau dengan kata lain pers diharapkan mampu bersikap netral.

Kebebasan untuk berpendapat serta perlindungan terhadap pers pada akhirnya melahirkan banyak media baru di Indonesia. Seiring dengan meningkatnya media di Indonesia, persaingan diantara mereka pun tidak dapat dihindari. Pers bukan lagi menjadi alat untuk menyebarkan informasi, namun juga menjadi ajang untuk mendapatkan keuntungan sebagai perusahaan pers. Persaingan-persaingan yang terjadi secara perlahan berakibat pada menurunnya kualitas dari media tersebut. Dalam rangka menjaga kebebasan pers nasional serta hak asasi manusia untuk mendapatkan informasi, maka dibentuklah suatu badan independen yang mengawasi dan menjaga kemerdekaan pers nasional yakti Dewan Pers sesuai dengan Pasal 15 dalam Undang-Undang Pers. Dewan pers memutuskan untuk mengukuhkan satu Kode Etik Jurnalistik yang wajib dipatuhi oleh seluruh pers yang ada di Indonesia.
Pengertian kode etik secara umum adalah panduan moral dan etika kerja yang disusun dan ditetapkan organisasi profesi seperti dokter, pengacara, guru, termasuk jurnalis. Sedangkan secara spesifik, Kode Etik Jurnalistik adalah kumpulan atau himpunan norma atau etika di bidang jurnalistik yang dibuat oleh, dari dan untuk wartawan. Aturanaturan ini dibuat sebagai kaidah penuntun moral dan etika para wartawan dalam menjalankan profesinya, agar para wartawan tidak bekerja sembarangan dan tetap menghargai serta menghormati hak orang lain yang dalam pelaksanaan maupun penegakannya, diawasi oleh Dewan Pers.

Dengan adanya kode etik jurnalistik, dewan pers memberikan batasan pada pelaku jurnalistik baik wartawan maupun perusahaan pers untuk bersama-sama menjaga kemerdekaan pers yang diberikan oleh pemerintah berdasarkan pada undang-undang pokok pers. Meski demikian masih banyak terjadi pelanggaran terhadap Kode Etik Jurnalistik. Hal tersebut menunjukan masih banyak kalangan menilai bahwa pers di Indonesia belum cukup dewasa untuk membatasi dirinya sendiri. Perkembangan pers yang pesat pasca reformasi tidak disertai dengan ketersediaan sumberdaya wartawan profesional dan perangkat manajemen pers yang berkualitas.

Pelanggaran terhadap kode etik sendiri sering kali diakibatkan oleh kegagalan dalam memahami setiap ketentuan yang terdapat dalam Kode Etik Jurnalistik. Selain itu kejadian multitafsir juga dipandang sebagai salah satu penyebab terjadinya pelanggaran. Namun adanya kepentingan untuk meningkatkan rating, kemudian adanya tuntutan kepada wartawan untuk mendapatkan berita dengan cepat serta adanya kepentingan pribadi oleh pemilik media dipandang 
menjadi sebab-sebab umum terjadinya pelanggaran-pelanggaran tersebut.

Dampak dari kegagalan tersebut berakibat pada kualitas pemberitaan yang tidak memenuhi kaidah-kaidah yang ditentukan dalam kode etik jurnalistik yang seyogyanya diterapkan oleh insane pers baik wartawan maupunn perusahaan pers sebagai benten pertama dalam meningkatkan dan menegakkan etika jurnalistik. Sebagai negara hukum, penyelesaian dan penegakan etika jurnalistik dan penyelesaian pelanggaran hukum jurnalistik sepenuhnya diatur oleh Undang-Undang Pers. Undang-undang pers merupakan landasan dalam penyelenggaraan pers nasional hingga perlindungan terhadap kemerdekaan pers nasional.

Dalam beberapa kasus pelanggaran kode etik jurnalistik dapat diselesaikan melalui internal perusahaan pers maupun melalui Dewan Pers sebagai lembaga yang berwenang menegakkan pelanggaran pers sesuai amanat undangundang pers. Salah satu kasus yang ramai diperbincangkan terkait pelanggaran kode etik jurnalistik serta upaya/tindakan yang dapat mengancam keberalngsungan kebebasan pers adalah kasus yang menimpa Radar Bogor. Media yang berdomisili di Kota Bogor itu mendapat intimidasi dan tindak kekerasan dari sejumlah massa yang mengatasnamakan kader Partai Demokrasi Indonesia Perjuangan (PDIP). ${ }^{1}$ Persoalan tersebut dipicu kekecewaan atas pemberitaan yang diterbitkan oleh Radar Bogor.

Pasca diterbitkannya berita tersebut, Loyalis dan kader dari Partai Demokrasi Indonesia Perjuangan (PDIP)

\footnotetext{
${ }^{1}$ Achmad Fardiansyah. (Oke News, 1 Juni 2018). IJTI : Penyerangan Massa PDIP Ke Kantor Radar Bogor Ancaman Kebebasan Pers. Dalam https://news.okezone.com/read/2018/06/01/338/1905 444/ijti-penyerangan-massa-pdip-ke-kantor-radarbogor-ancaman-kebebasan-pers diakses 20 November 2018.
}

yang tidak terima terhadap pemberitaan tersebut langsung mendatangi kantor Radar Bogor pada sore harinya dan melakukan tindakan intervensi dan sempat melakukan tindakan kekerasan kepada salah satu staff Radar Bogor. ${ }^{2}$ Perbuatan tersebut tentu bertentangan dengan ketentuan undang-undang pokok pers terkait keberatan pada suatu berita oleh media pers. Keberatan atas suatu pemberitaan media, baik atas kelalaian terhadap kode etik jurnalistik maupun keberatan atas konten berita sesuai dengan ketentuan undang-undang melalui hak jawab dan koreksi.

Penyelesaian kasus tersebut diadukan melalui dewan pers, yang kemudian mengeluarkan surat keputusan bahwa Dewan Pers menilai berita Radar Bogor, edisi Rabu, 30 Mei 2018, berjudul 'Ongkang-ongkang Kaki Dapat Rp 112 juta' melanggar kode etik jurnalistik. ${ }^{3}$ Penyelesaian pelanggaran etika jurnalistik sesuai dengan keputusan dewan pers memberikan rekomendasi untuk hak jawab dan permintaan maaf pada Megawati. Selain itu, keputusan dewan pers pun mengarahkan pada perbuatan dan/atau tindakan penyerangan untuk diberikan tindakan sepatutnya, karena berpotensi mangancam kemerdekaan pers. ${ }^{4}$ Berdasarkan uraian tersebut diatas, penelitian ini bertujuan untuk menguraikan bentuk perlindungan hukum terhadap kemerdekaan pers nasional dari upaya intervensi pihakpihak yang merasa dirugikan dari informasi yang diterbitkan oleh media ditinjau dari undang-undang pokok pers.

\footnotetext{
${ }^{2}$ Ibid.

${ }^{3}$ Fajar Pratama. (Detik News, 6 Juni 2018). Dewan Pers Vonis Radar Bogor Langgar Etik, Sesalkan Aksi Massa PDIP. Dalam https://news.detik.com/berita/d4055506/dewan-pers-vonis-radar-bogor-langgar-etiksesalkan-aksi-massa-pdip diakses 20 November 2018.

${ }^{4}$ Pernyataan Dewan Pers No. 1/P-DP/VI/2018 Tentang Pemberitaan Yang Berujung Penyerangan Terhadap Kantor Redaksi Radar Bogor.
} 
Dalam penelitian ini, fokus terhadap kajian perlindungan hukum pers mengenai peran pemerintah dan insan pers nasional dalam menjaga kemerdekaan pers nasional dalam kerangka hukum positif serta hukum pers.

\section{B. METODE PENELITIAN}

Penelitian ini merupakan model penelitian kualitatif yang bersifat deskriptif analitis ${ }^{5}$, dengan maksud mengumpulkan data selengkap mungkin untuk menggambarkan fakta-fakta secara sistematis dan terintegrasi melalui data primer maupun data sekunder. Penelitian ini menggunakan pendekatan yuridis normatif $^{6}$, suatu pendekatan yang mengkonsepsikan hukum sebagai norma, kaidah atau asas untuk menganalisis data secara sistematis dengan peraturanperaturan yang ada, khususnya peraturan yang berkaitan dengan undang-undang pokok pers, kode etik jurnalistik maupun peraturan dewan pers. Dalam analisis pembahasan permasalahan sumbersumber yang digunakan berupa undangundang, keputusan dewan pers hingga sumber dari berbagai literarur maupun media cetak dan media online.

\section{KERANGKA KONSEPTUAL}

Perlindungan hukum diartikan sebagai perlindungan hak setiap orang untuk mendapatkan perlakuan dan perlindungan oleh hukum atau perundang-undangan. ${ }^{7}$ Salim menjabarkan bentuk perlindungan hukum kedalam dua bentuk, yaitu perlindungan

\footnotetext{
5 Soerjono Soekanto, Pengantar Penelitian Hukum, Cet. Ke-3 (Jakarta: UI Press, 1986). Hlm. 9-10

6 Soerjono Soekanto and Sri Mamudji, Penelitian Hukum Normatif (Jakarta: Rajawali Press, 2006). Hlm. 14-15

7 Aji Mulyana, "Perlindungan Hukum Terhadap Perempuan Dan Anak Akibat Tindak Pidana Abortus Provocatus Criminalis," Jurnal Wawasan Yuridika 1, no. 2 (2017): 139-154.
}

preventif dan perlindungan represif. ${ }^{8}$ Dengan demikian, konsespsi Negara hukum memberikan jaminan perlindungan secara preventif yaitu terhadap perbuatan-perbuatan yang bertentangan dengan peraturan hukum formil yang ditetapkan oleh Negara. Dalam kegiatan jurnalistik, maka digunakan undang-undang pokok pers sebagai jaminan perlindungan terhadap kegiatan dan/atau prilaku jurnalistik. Sedangkan secara represif, bentuk perlindungan hukum berupa penegakkan hukum terhadap perbuatan-perbuatan yang bertentangan dengan peraturan perundang-undangan.

Journalisme atau Jurnalistik menurut MacDougall adalah kegiatan menghimpun berita, mencari fakta dan melaporkan peristiwa. ${ }^{9}$ Dalam praktiknya, saat ini kegiatan menghimpun berita dari sebuah peristiwa menjadi suatu pekerjaan, oleh karena itu orang yang melakukan kegiatan tersebut sering disebut jurnalis atau orang yang melakukan pekerjaan jurnalistik. ${ }^{10}$

Kode etik jurnalistik merupakan panduan prilaku dalam kegiatan jurnalisme yang merupakan hasil kesepakatan bersama. Dalam rangka melaksanakan kemerdekaan mengeluarkan pikiran sesuai amanat konstitusional. Untuk menjamin kemerdekaan pers dan memenuhi hak publik untuk memperoleh informasi yang benar, maka diperlukan landasan moral dan etika profesi sebagai pedoman operasional dalam menjaga kepercayaan publik dan menegakkan integritas serta profesionalisme. Dalam penilaian akhir pelanggarang kode etik jurnalistik

\footnotetext{
${ }^{8}$ Salim and Erlies Septiana Nurbani, Penerapan Teori Hukum Pada Tesi Dan Disertasi, Cet. Ke-2 (Jakarta: Raja Grafindo Persada, 2013). hlm. 264.

${ }^{9}$ Hikmat Kusumaningrat and Purnama Kusumaningrat, Jurnalistik, Teori \& Praktik, Cetakan Ke (Bandung: Remaja Rosdakarya, 2014). hlm. 15

${ }^{10} \mathrm{Ibid}$
} 
dilakukan oleh dewan pers sebagai lembaga independen pers nasional, berdasarkan pengaduan dan laporan masyarakat. Dalam penindakkan pengaduan dewan pers memiliki kewenangan melalui mekanisme suratmenyurat, mediasi dan ajudikasi. Namun, sanksi atas pelanggaran kode etik jurnalistik dikembalikan atau dilakukan oleh organisasi wartawan dan/atau perusahaan pers.

$\begin{array}{llr}\text { Untuk melindungi kegiatan } \\ \text { jurnalistik } & \text { nasional serta }\end{array}$
mengembangkan dan meningkatkan kehidupan pers nasional diamanatkan oleh undang-undang untuk dibentuk suatu lembaga yang independen yakni dewan pers. Peran dan fungsi dari dewan pers tersebut antara lain : melindungi kemerdekaan pers dari campur tangan pihak lain, melakukan pengkajian untuk pengmbangan kehidupan pers; menetapkan dan mengawasi pelaksanaan kode etik jurnalistik; memberikan pertimbangan dan mengupayakan penyelesaian pengaduan masyarakat atas kasus-kasus yang berhubungan dengan pemberitaan pers; mengembangkan komunikasi antara pers, masyarakat dan pemerintah, memfasilitasi organisasiorganisasi pers dalam menyusun peraturan-peraturan dibidang pers; dan meningkatkan kualitas profesi wartawan; dan mendata perusahaan pers.

Hukum dan masyarakat merupakan suatu yang tumbuh secara bersama dalam rangka menciptakan kerukunan, ketertiban dan ketentraman sebagai mahluk sosial. Hukum dibutuhkan untuk menjadi jaminan bagi setiap orang dalam memepertahankan hak-haknya dalam kehidupan bersama dalam bermasyarakat dan bernegara. ${ }^{11}$ Hukum memiliki sifat mengatur dan

11 Fuqoha Fuqoha, "Perlindungan Hukum Terhadap Kesempatan Kerja Bagi Masyarakat Lokal Di Kota Cilegon," Jurnal Wawasan Yuridika 2, no. 2 (2018): 35-57. memaksa, karena adanya hukum untuk menjamin tata tertib dalam masyarakat. Kehidupan masyarakat dapat menjadi tertib dan teratur apabila ditunjang oleh tatanan hukum yang memberikan jaminan bahwa setiap manusia harus saling menghormati hak manusia lainnya, jika tidak menghormati dan mengindahkan tatanan hukum, maka akan ada sanksi atas perbuatannya tersebut. $^{12}$

Oleh karena itu, dengan perlindungan terhadap kemerdekaan pers melalui kebijakan hukum dalam penyelenggaraan pers diharapkan dapat menjaga dan melindungi proses dan penyebaran informasi baik media cetak maupun media elektronik. Hal tersebut tertuang dalam ketentuan UndangUndang Pers Nomor 40 Tahun 1999 dalam Pasal 2 bahwa kemerdekaan pers adalah salah satu wujud kedaulatan rakyat yang berdasarkan prinsip-prinsip demokrasi, keadilan dan supremasi hukum. Selanjutnya dalam Pasal 4 terdapat ketentuan bahwa (1) kemerdekaan pers dijamin sebagai hak asasi warga Negara; (2) terhadap pers nasional tidak dikenakan penyensoran, pembredelan atau pelarangan penyiaran; (3) untuk menjamin kemerdekaan pers, pers nasional mempunyai hak mencari, memperoleh menyebarluaskan gagasan dan informasi; dan (4) dalam mempertanggungjawabkan pemberitaan didepan hukum, wartawan mempunyai hak tolak.

Berlandaskan pada ketentuanketentuan yang dituangkan dalam undang-undang pokok pers menunjukan adanya kebebasan bagi insan pers untuk mengumpulkan dan menyampaikan informasi sebagai bagian dari kemerdekaan pers. Dengan demikian, tidak dibenarkan adanya perlakuan oleh siapapun maupun pihak manapun yang

\footnotetext{
${ }^{12}$ Chainur Arrasjid, Dasar-Dasar Ilmu Hukum, Edisi 1 (Jakarta: Sinar Grafika, 2006). Hlm.22
} 
dapat mengancam kemerdekaan pers nasional. Perlindungan hukum terhadap ancama dalam penyelenggaraan pers diatur sesuai ketentuan dalam Pasal 18 Ayat (1) yaitu :

Setiap orang yang
secara melawan
hukum dengan sengaja
melakukan tindakan
yang berakibat
menghambat atau
menghalangi ketentuan
pelaksanaan kan
Pasal 4 Ayat (2) dan
(3) dipidana dengan
pidana penjara paling
lama 2 (dua) tahun
atau denda paling
banyak Rp.
$500.000 .000,00$ (lima
ratus juta rupiah).
Dengan demikian, keberadaan
hukum dalam tatanan masyarakat sangat penting dalam rangka menjaga ketertiban dan kerukunan antarkepentingan masyarakat. Dalam kasus pemberitaan media Radar Bogor dan penyerangan oleh sekelompok orang yang kecewa atas pemberitaan tersebut, memiliki konsekuensi hukum yang mengikat kedua belah pihak. Dalam pemberitaan pers dan penyerangan kasus Radar Bogor, persoalan hukum diarahkan dan diatur dengan undang-undang pers. Sedangkan persoalan hukum, yang berdampak pada pengrusakan diatur dalam undang-undang pers dan kitab undang-undang hukum pidana.

\section{PEMBAHASAN}

\section{Perlindungan Hukum dalam Menjaga Kemerdekaan Pers Nasional}

Sebagai Negara hukum, maka segala sesuatu kegiatan maupun tindakan harus berdasarkan aturan hukum. Undangundang mengatakan bahwa kemerdekaan pers sebagai salah satu wujud kedaulatan rakyat. Oleh karena itu, undang-undang tentang pers merupakan supremasi hukum bagi kegiatan jurnalisme maupun pers di Indonesia. Sebagai bentuk perlindungan hukum terhadap kegiatan jurnalistik dan pers nasional, maka diamanatkan pembentukan lembaga independen yang menanungi dan melindungi kemerdekaan pers nasional. Dewan Pers sebagai lembaga independen yang didirikan berdasarkan Undang-Undang No.40 Tahun 1999 Tentang Pers dalam Pasal 15 Ayat (1) dan (2) diberikan amanat dalam rangka menghidupkan dan melindungi pers, yang berbunyi :

1) Dalam upaya mengembangkan kemerdekaan pers dan meningkatkan kehidupan pers nasional, dibentuk Dewan Pers yang independen.

2) Dewan Pers melaksanakan fungsifungsi sebagai berikut:

a. Melindungi kemerdekaan pers dari campur tangan pihak lain;

b. Melakukan pengkajian untuk pengembangan kehidupan pers;

c. Menetapkan dan mengawasi pelaksanaan Kode Etik Jurnalistik;

d. Memberikan pertimbangan dan mengupayakan penyelesaian pengaduan masyarakat atas kasus-kasus yang berhubungan dengan pemberitaan pers;

e. Mengembangkan komunikasi antara pers, masyarakat, dan pemerintah;

f. Memfasilitasi organisasiorganisasi pers dalam menyusun peraturan-peraturan di bidang pers dan meningkatkan kualitas profesi kewartawanan; dan

g. Mendata perusahaan pers; 
Aturan hukum sebagai suatu pijakan bagi kegiatan pers mengenai apa yang harus dilakukan dan diperbolehkan. Wiener dalam Haris Sumadiria menggambarkan hukum sebagai suatu sistem kontrol searah yang dilakukan oleh suatu central organ yang memiliki kekuasaan. ${ }^{13}$ Dalam paradigma hukum cybernatics hukum dipandang sebagai perintah dari penguasa yang harus dipatuhi dan ditaati oleh masyarakat (law as command of the law giver). ${ }^{14}$ Dengan demikian merujuk pandangan Weiner tersebut perlindungan hukum terhadap kemerdekaan pers nasional di Indonesia telah ditetapkan dan diberikan oleh pemerintah melalui ketentuan perundangundangan tentang pers.

Dewan pers sebagai sebuah lembaga yang dibentuk berdasarkan ketentuan undang-undang tentang pers, yang memiliki tujuan untuk menjaga dan melindungi kemerdekaan pers nasional diberikan kewenangan untuk menyelesaikan permasalahanpermasalahan yang berkaitan atau ditimbulkan oleh pers. Kewenangan dewan pers terkait permasalahan pers yakni meliputi memberikan surat, mediasi dan ajudikasi. Penyelesaian permasalahan yang timbul akibat kegiatan pers pada dewan pers meliputi surat-menyurat, pembuatan risalah, mengeluarkan pernyataan dan pernyataan, penilaian dan rekomendasi.

Kemerdekaan pers yang dijamin oleh Konstitusi dan undang-undang seharusnya dapat melindungi kegiatan jurnalistik di Indonesia. Menjadi tanggungjawab bersama dan dibawah pengawasan dewan pers sebagai lembaga yang menaungi segala bentuk dan kegiatan jurnalistik agar kemerdekaan pers yang dicita-citakan tetap terjaga dan

13 A.S. Haris Sumandiria, Jurnalistik Indonesia: Menulis Berita Dan Feature, Cet. Ke-5 (Bandung: Remaja Rosdakarya, 2014).

${ }^{14}$ Ibid. terlaksana di indonesia. Sesuai ketentuan yang dituangkan dalam Pasal 2 UndangUndang 40 Tahun 1999 bahwa kemerdekaan pers adalah salah satu wujud kedaulatan rakyat yang berasaskan prinsip-prinsip demokrasi, keadilan dan supremasi hukum.

Menjaga kemerdekaan pers nasional, menjadi beban dan tanggungjawab dewan pers sebagai institusi yang menaungi pelaku jurnalistik dan perusahaan-perusahaan pers nasional. Perlu terus dilakukan kajian-kajian yang mendorong kemerdekaan pers nasional tetap terjaga dan terkebiri dari potensipotensi yang mengakibatkan kebebasan pers dan/atau kemerdekaan pers tidak dapat dinikmati baik oleh insan pers maupun oleh masyarakat. Oleh karena itu, kemerdekaan pers sebagai wujud kedaulatan rakyat dalam memperoleh informasi harus dijaga oleh semua elemen, baik oleh dewan pers, pelaku jurnalistik, pemerintah hingga masyarakat.

Peran serta masyarakat dalam menjaga kemerdekaan pers sesuai ketentuan dalam undang-undang tentang pers nomor 40 tahun 1999 pasal 17 Ayat (1) dan (2) yang berbunyi :

1) Masyarakat dapat melakukan kegiatan untuk mengembangkan kemerdekaan pers dan menjamin hak memperoleh informasi yang diperlukan.

2) Kegiatan sebagaimana dimaksud dalam ayat (1) dapat berupa:

a. Memantau dan melaporkan analisis mengenai pelanggaran hukum, dan kekeliruan teknis pemberitaan yang dilakukan oleh pers;

b. menyampaikan usulan dan saran kepada Dewan Pers dalam rangka menjaga dan 
meningkatkan kualitas pers nasional.

Bentuk perlindungan hukum lainnya yang dilakukan untuk menjaga kemerdekaan pers nasional yang diberlakukan oleh dewan pers salah satunya adalah penerapan Kode Etik Jurnalistik (KEJ) yang menjadi pedoman bagi insan pers di Indonesia. Etika pers mempersoalkan bagaimana seharusnya pers itu dilaksanakan agar dapat memenuhi fungsinya dengan baik. ${ }^{15}$ Namun demikian, upaya menjaga kemerdekaan pers dengan adanya undangundang pers dan kode etik jurnalistik sebagai pedoman bagi insan pers tetap memunculkan persoalan dalam teknis jurnalistik di Indonesia. Kelemahan dewan pers dalam implementasi kode etik jurnalistik pada jurnalis dan/atau wartawan adalah mengembalikan kepada perusahaan pers masing-masing. Sehingga pelanggaran kode etik jurnalistik, selalu terjadi berulang karena diselesaikan oleh pihak internal perusahaan media/pers.

Kewenangan dewan pers yang tidak dapat menyelesaiakan perkara yang diakibatkan kegiatan jurnalistik, mengakibatkan lemahnya peran dewan pers. Pelanggaran dalam kode etik jurnalistik sering menimbulkan pelanggaran pidana atau sering disebut "delik pers" yang berarti semua tindak pidana atau pelanggaran yang dilakukan melalui media massa. ${ }^{16}$ Definisi delik pers oleh ahli dijelaskan bahwa setiap pengumuman dan/atau penyebarluasan pikiran melalui penerbitan pers yang meliputi penghinaan, pencemaran nama baik serta fitnah yang dilakukan insan pers. ${ }^{17}$ Delik pers merupakan bagian dari delik khusus yang berlaku umum yang tertuang dalam Kitab Undang-Undang

\footnotetext{
${ }^{15}$ Ibid. hlm. 239

${ }^{16}$ Kusumaningrat, Hikmat \& Purnama Kusumaningrat, Op.cit. hlm. 109

17 Sumandiria, Jurnalistik Indonesia: Menulis Berita Dan Feature. Op. cit. hlm. 232
}

Hukum Pidana (KUHP) yang dilakukan oleh insan pers dan memenuhi unsurunsur pidana. Namun demikian, melalui Undang-Undang Nomor 40 Tahun 1999 Tentang Pers telah mengesampingkan upaya-upaya kriminalisasi terhadap pers nasional dalam rangka menjaga kemerdekaan pers nasional di Indonesia.

$$
\text { Dalam rangka menjaga }
$$

kemerdekaan pers, dewan pers selaku lembaga yang dibentuk untuk melindungi kemerdekaan dan menumbuhkembangkan pers nasional harus mampu mengatasi permasalahan yang ditimbulkan akibat kegiatan jurnalistik. Pelanggaran dalam kegiatan jurnalistik yang mengacu pada kode etik jurnalistik yang ditetapkan oleh dewan pers harus menjadi landasan etika dan hukum. Dalam penegakkan hukum (law enforcement), pelanggaran kegiatan jurnalistik, seharusnya selesai pada dewan pers. Pelanggaran kegiatan jurnalistik tidak diarahkan pada "delik pers" (kriminalisasi pers), Prof. Bagir Manan mengemukakan penegakkan hukum terhadap pelanggaran pers, bukan untuk mematikan pers, tetapi untuk memelihara dan membesarkan tanggungjawab dan disiplin pers. $^{18}$

Dalam upaya menjaga

kemerdekaan pers nasional yang telah diupayakan dan diperjuangkan oleh insan pers dan/atau pemerintah melalui berbeagai regulasi yang dikeluarkan yang memeberikan jaminan dan perlindungan hukum untuk segenap insan pers. Selanjutnya menjadi tanggungjawab bersama antara insan pers, pemerintah dan juga masyarakat untuk bersama-sama menjaga kedaulatan dan kebebasan pers nasional agar tidak tercipta upaya-upaya yang dapat mengancam dan menghalangi kebebasan pers dalam bingkai kemerdekaan pers nasional.

\footnotetext{
18 Bagir Manan, Menjaga Kemerdekaan Pers Di Pusaran Hukum, Cet. Ke-4 (Jakarta: Dewan Pers, 2014). Hlm. 5
} 
Dalam pandangan Prof. Bagir Manan untuk memelihara kebebasan pers terdapat beberapa hal yang wajib dilaksanakan antara lain; pertama, mengembangankan dan memelihara demokrasi; kedua, memelihara dan mengembangkan Negara hukum; ketiga, pers senantiasa memelihara tanggungjawab dan disiplin; dan keempat, kebebasan pers bukan suatu hadiah yang cuma-cuma, melainkan hasil perjuangan dan kerja keras. ${ }^{19}$ Dengan demikian, kemerdekaan pers nasional tidak akan dirasakan oleh insan pers manakala pelaku pers, pemerintah dan juga masyarakat tidak serta merta menjaga kebebasan pers nasional seperti saat ini.

Konsepsi demokrasi menjadi pilar penting dalam perlindungan kemerdekaan pers, karena salah satu prinsip demokrasi adalah adanya kebebasan pers dalam menggali dan menyampaikan informasi pada publik dan/atau masyarakat secara luas. Konsepsi demokrasi tentu harus didukung oleh kedaulatan pers yang dijamin melalui kebijakan hukum dalam bentuk perundang-undangan yang menjadi landasan dalam pelaksananaan, perlindungan dan peneggakan hukum yang timbul dari kegiatan pers. Upaya perlindungan tersebut telah dilakukan oleh Negara melalui ketentuan-ketentuan yang dituangkan dalam Undang-Undang No.40 Tahun 1999 Tentang Pers.

Perlindungan hukum dalam rangka menjaga kemerdekaan pers nasional yang telah diatur melalui undang-undang pers ditegaskan dalam Pasal 18 Ayat (1) bahwa Setiap orang yang secara melawan hukum dengan sengaja melakukan tindakan yang berakibat menghambat atau menghalangi pelaksanaan ketentuan Pasal 4 Ayat (2) dan Ayat (3) dipidana dengan pidana penjara paling lama 2 (dua) tahun atau denda paling banyak Rp. 500.000.000,00 (Lima ratus juta rupiah). Berdasarkan pada

${ }^{19}$ Ibid. hlm 4-6 ketentuan tersebut, menunjukan penguasa dalam hal ini pemerintah dan juga dewan pers berupaya untuk memberikan jaminan kebebasan dari intervensi dari pihak manapun. Oleh karena itu, kemerdekaan pers nasional akan tetap dirasakan oleh segenap insan pers dan juga masyarakat umum untuk memperoleh informasi.

Upaya perlindungan kemerdekaan pers yang diperjuangkan oleh semua pihak pada akhirnya didasarkan pada kebijakan hukum tentang pers yang telah ditetapkan dalam perundang-undangan. Namun demikian, menjaga kemerdekaan pers nasional di Indonesia perlu terus ditekankan pada semua element yang terkait dengan pers. Diantara upaya-upaya yang dapat dilakukan, antara lain dengan mengedepankan pandangan pada Social Responsbility Theory sebagai salah satu dari Fourth Theories of The Press. ${ }^{20}$ Pers nasional di Indonesia akan dapat bekerja secara professional dan memenuhi dan mentaati standar etika dan hukum pers yang ditetapkan oleh pemerintah dan/atau dewan pers sebagai penjaga kemerdekaan pers nasional.

Dalam pandangan pers dalam Social Responsbility Theory kebebasan informasi merupakan hak publik yang harus disampaikan oleh pers secara bertanggungjawab tanpa ada pengurangan informasi. Dalam perjalanannya konsep Social Responsbility Theory memberikan 5 syarat mutlak sebagai pers yang bertanggungjawab yang diformulasikan dalam Commission on The Freedom of The Press, antara lain : ${ }^{21}$

1) Media harus menyajikan berita-berita peristiwa sehari-hari yang dapat dipercaya, lengkap, dan cerdas dalam konteks yang memberikannya makna;

\footnotetext{
20 Edy Susanto, Mohammad Taufik Makarao, and Hamid Syamsudin, Hukum Pers Di Indonesia (Jakarta: Rineka Cipta, 2010). hlm. 28.

${ }^{21}$ Ibid.
} 
2) Media harus berfungsi sebagai forum untuk pertukaran komentar dan kritik;

3) Media harus memproyeksikan gambaran yang benarbenar mewakili dari kelompok-kelompok konstituen dalam masyarakat;

4) Media harus menyajikan dan menjelaskan tujuantujuan dan nilai-nilai masyarakat; dan

5) Media harus menyediakan akses penuh terhadap informasi-informasi yang tersembunyi pada suatu saat.

Dewan pers dan semua pelaku pers perlu mengedepankan konsepsi Social Responsbility Theory sebagai bagian dari upaya bersama dalam menjaga kemerdekaan pers nasional. Dengan demikian, keberadaan pers di Indonesia dengan segala kebebasan pers yang dijamin oleh konstitusi dan perundangundangan pers menjadi sebuah tolak ukur kedaulatan pers dalam bingkai Negara demokrasi konstitusional. Kebebasan dan/atau kemerdekaan pers menjadi penghubung antara pemerintah dan rakyat berdasarkan konsepsi pers yang bertanggungjawab.

Kemerdekaan pers nasional yang sedang dinikmati oleh insan pers di Indonesia dapat tetap terjaga dan terlindungi, apabila seluruh insan pers nasional mengedepankan nilai-nilai etika (Kode Etik Jurnalistik) yang dilandaskan pada konsep Social Responsbility Theory sebagai dasar pelaksanaan pers yang profesional. Perlindungan hukum terhadap penyeleggaraan pers nasional telah diberikan melalui ketentuan perundangundangan pers, sehingga tidak perlu ada kekhawatiran dalam kegiatan jurnalistik selama memenuhi kaidah-kaidah etik dan norma hukum yang berlaku. Bagian akhir dalam perlindungan hukum demi menjaga kemerdekaan pers nasional adalah penegakkan hukum pers itu sendiri oleh pemerintah dan perlindungan hukum terhadap upaya-upaya dari pihak manapun yang dapat mengancam runtuhnya kebebasan dan kemerdekaan pers nasional.

\section{Penegakkan Hukum Terhadap Intervensi pada Media Pers di Indonesia}

Ketentuan hukum yang telah dituangkan dalam perundangundangan tentang pers yang tertuang dalam Undang-Undang Nomor 40 Tahun 1999 Tentang Pers dalam Pasal 18 yaitu :

1) Setiap orang yang secara melawan hukum dengan sengaja melakukan tindakan yang berakibat menghambat atau menghalangi pelaksanaan ketentuan Pasal 4 Ayat (2) dan Ayat (3) dipidana dengan dengan pidana penjara paling lama 2 (dua) tahun atau denda paling banyak Rp. 500.000.000,00 (limaratus juta rupiah).

2) Perusahaan pers yang melanggar ketentuan Pasal 5 Ayat (1) dan Ayat (2), serta Pasal 13 dipidana dengan pidana denda paling banyak Rp. 500.000.000,00 (limaratus juta rupiah).

3) Perusahaan pers yang melanggar ketentuan Pasal 9 Ayat (2) dan Pasal 12 dipidana dengan denda paling banyak Rp. 100.000.000,00 (seratus juta rupiah).

Berlandaskan pada ketentuan tersebut bahwa intervensi terhadap media pers tidak dibenarkan secara 
hukum dan merupakan bagian dari perbuatan melawan hukum dalam undang-undang pers. Dalam Blacklaw Dictionary intervensi diartikan "intervention may or may not involve the use of force". ${ }^{22}$ Dengan demikian, intervensi sebagai upaya penggunaan kekerasan sebagai bagian untuk mempengaruhi pihak lain. Oleh karena itu, siapapun yang melakukan perbuatan secara melawan hukum yang dapat menghambat dan/atau menghalangi pers nasional merupakan bentuk intervensi terhadap kebebasan pers.

Dalam ketentuan undangundang pers terkait perbuatan secara melawan hukum bedasarkan Pasal 4 Ayat (2) yaitu terhadap pers nasional tidak dikenakan penyensoran, pembredelan atau pelarangan penyiaran. Ketentuan tersebut menggambarkan bahwa intervensi dalam bentuk apapun terhadap pers nasional merupakan ancaman terhadap kemerdekaan dan kebebasan pers nasional. Menurut Munir Fuady, pembatasan terhadap kebebasan pers merupakan bagian dari anti demokrasi yang meliputi pengekangan pers (restraint), pembredelan pers (breide), sensor (censor), atau pelarangan sebelum terbit (prior restraint). ${ }^{23}$

Persoalan pers yang berkenaan dengan adanya intervensi dimungkinkan lahir dari pemerintahan yang otoriter. Namun, pasca reformasi dan ditetapkannya undang-undang pers di tahun 1999 menunjukan adanya itikad baik dari pemerintahan dalam kebabasan pers. Oleh karena, kebebasan dan kemerdekaan pers tersebut harus dijaga secara bersama-

\footnotetext{
${ }^{22}$ Bryan A. Garner, Black's Law Dictionary, ed. Bryan A. Garner, Eight (St. Paul: Thomson Business, 2004). p.840.

${ }^{23}$ Munir Fuady, Kosep Negara Demokrasi, Cet. Ke-1 (Bandung: Refika Aditama, 2010). hlm. 243.
}

sama oleh insan pers, pemerintah maupun masyarakat. Salah satu bentuk ancaman terhadap kemerdekaan pers dan perbiatan secara melawan hukum adalah kasus pelanggaran kode etik yang dilakukan oleh Radar Bogor yang berdampak pada upaya penyerangan terhadap perusahaan/media Radar Bogor oleh sekelompok orang simpatisan yang merasa tersinggung akibat pemberitaan tersebut.

Pelanggaran secara melawan hukum tersebut bermula dari berita di Radar Bogor yang bernada sindiran terhadap Megawati Soekarnoputri. Berikut ini isi berita Radar Bogor yang berjudul "Ongkang-ongkang Kaki Dapat Rp 112 juta," terbit pada hari Rabu tanggal 30 Mei 2018 sebagai berikut : ${ }^{24}$

\section{JAKARTA-RADAR}

BOGOR, Badan Pembinaan Ideologi Pancasila (BPIP) tengah menjadi bahan olokolok. Penyebabnya adalah gaji mereka yang setinggi langit. Untuk sang ketua Dewan Pengarahnya saja negara mesti merogoh kocek sebesar Rp.112,5 juta. Entah apa yang mereka kerjakan nanti hingga berhak bergaji super tinggi.

Penghasilan bulanan Megawati Soekarnoputri dipastikan bertambah melimpah. Sebagai Ketua Dewan Pengarah BPIP, Mega berhak mendapat Rp.112,5 juta per bulan. Gaji itu setara dengan penghasilan ketua

24 Radbogmin2. (radarbogor.id, 30 Mei 2018). Ongkang-ongkang Kaki Dapat Rp.112 Juta dalam http://www.radarbogor.id/2018/05/30/ongkangongkang-kaki-dapat-rp112-juta/ diakses pada 20 November 2018. 
Mahkamah Agung dan ketua Mahkamah

Konstitusi. Dan, jauh lebih tinggi dari apa yang diterima Joko Widodo sebagai Presiden RI yang hanya Rp.60 jutaan.

"Orang-orang yang sudah sepuh itu yang menjadi BPIP, kemudian mengejutkan hanya ongkang-ongkang, hanya tukar pikiran wah (digaji) Rp.100 juta lebih," kata pendiri PAN, Amien Rais di Aula Sarbini, Cibubur, Jakarta Timur, kemarin (29/5).

Bukan hanya Megawati yang bergaji selangit di BPIP. Menilik Peraturan Presiden Nomor 42 Tahun 2018 yang diteken presiden, para anggota dewan pengarah berhak mendapat Rp.100,8 juta per bulan, lalu kepala BPIP Rp.76,5 juta, wakil kepala Rp.63,7 juta, deputi Rp.51 juta dan staf khusus Rp.36,5 juta.

Persoalan pemberitaan oleh Radar Bogor merupakan bentuk pelanggaran kode etik jurnalistik, hal tersebut sesuai dengan keputusan dewan pers yang telah menerima laporan dan memberikan putusan dalam bentuk Surat Pernyataan Dewan Pers Nomor 1/P-DP/VI/2018 tentang Pemberitaan yang Berujung Penyerangan terhadap Kantor Redaksi Radar Bogor yang berisi sebagai berikut :

1) Dewan Pers menilai berita Radar Bogor, edisi Rabu, 30 Mei 2018 berjudul "Ongkang-ongkang
Kaki dapat $\mathrm{Rp} 112$ Juta", melanggar Kode Etik jurnalistik Pasal 1: "Wartawan Indonesia bersikap independen, menghasilkan berita yang akurat, berimbang, dan tidak beritikad buruk" dan Pasal 3: "Wartawan Indonesia selalu menguji informasi, memberitakan secara berimbang, tidak mencantumkan fakta dan opini yang menghakimi, serta menerapkan asas praduga tak bersalah". Dewan Pers merekomendasikan

agar Radar Bogor memuat Hak Jawab dari Megawati Soekarnoputri atau yang mewakili disertai dengan permintaan maaf kepada Megawati

Soekarnoputri dan pembaca. Kalimat permintaan maaf dimuat di bagian akhir dari Hak Jawab

2) Sesuai dengan spirit Undang Undang Nomor 40 Tahun 1999 tentang Pers, penyelesaian semua kasus terkait pemberitaan pers dilakukan melalui mekanisme hak jawab, hak koreksi dan atau permintaan maaf. Intimidasi dan dugaan kekerasan terhadap 
Radar Bogor tidak dapat dibenarkan, dan berpotensi melanggar Pasal 18 Ayat (1)," Setiap orang yang secara melawan hukum dengan sengaja melakukan tindakan yang berakibat menghambat atau menghalangi

pelaksanaan ketentuan Pasal 4 Ayat (2) dan Ayat (3) dipidana paling lama 2 (dua) tahun atau dengan denda paling banyak Rp 500.000.000,(Lima ratus Juta Rupiah)".

3) Terhadap dugaan adanya tindak pidana dalam kasus ini, Dewan Pers mengimbau aparat hukum yang berwenang untuk mengambil tindakan sepatutnya, demi tegaknya kemerdekaan pers.

\section{Gambar 1}

Berita Radar Bogor \& Surat Pernyataan Dewan Pers

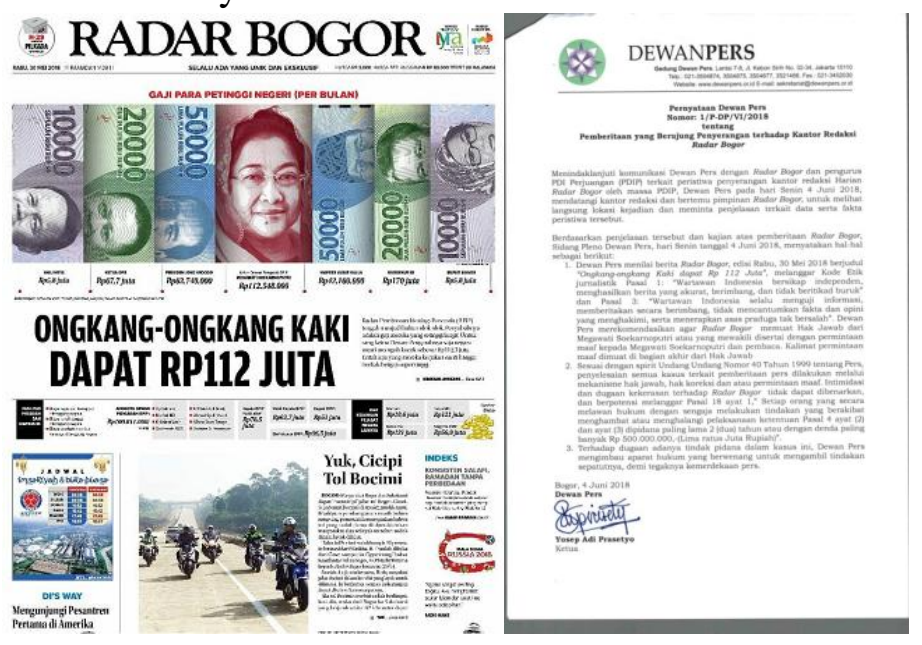

Melalui keputusan yang dikeluarkan oleh dewan pers menunjukan peran dewan pers sebagai lembaga independen yang memiliki tugas dan tanggungjawab dalam menata dan mengawasi perusahaan pers dan kegiatan jurnalistik sebagai bentuk perlindungan hukum sekaligus pengakkan etika dan hukum pers, sebagaimana tertuang dalam setiap kalimat dalam putusan tersebut. Dalam putusannya Dewan Pers menyatakan radar Bogor telah melanggar Kode Etik Jurnalistik (KEJ) dalam Pasal 1 dan Pasal 3. Perbuatan tersebut sangat disanyangkan dilakukan oleh insan pers karena bertentangan dengan kode etik jurnalistik serta tidak sesuai Social Responsbility Theory sebagai salah satu dari Fourth Theories of The Press.

Kode Etik Jurnalistik dalam Pasal 1 bahwa Wartawan Indonesia bersikap independen, menghasilkan berita yang akurat, berimbang, dan tidak beritikad buruk serta Pasal 3 yaitu Wartawan Indonesia selalu menguji informasi, memberitakan secara berimbang, tidak mencantumkan fakta dan opini yang menghakimi, serta menerapkan asas praduga tak bersalah. Mengandung rumusan dari pandangan Social Responsbility Theory yang diformulasikan dalam Commission on The Freedom of The Press bahwa media harus menyajikan berita-berita peristiwa sehari-hari yang dapat dipercaya, lengkap, dan cerdas dalam konteks yang memberikannya makna.

Terlepas dari pelanggaran Kode Etik Jurnalistik yang dilakukan oleh pihak Radar Bogor, dalam putusan lainnya menunjukkan upaya penegakkan hukum pers dengan memberikan rekomendasi pada pihak yang berwenang untuk 
menindaklanjuti persoalan yang dapat mengancam kebebasan dan/atau kemerdekaan pers nasional. Hal tersebut merujuk pada adanya intimidasi dan dugaan kekerasan terhadap Radar Bogor oleh sekelompok orang tertentu dan/atau simpatisan Partai Demokrasi Indonesia Perjuangan (PDIP). Berdasarkan pernyataan Pimpinan Redaksi Radar Bogor Tegar Bagja ${ }^{25}$, bahwa sangat disayangkan adanya sikap arogansi ketika massa mendatangi kantor Radar Bogor yang dating sambil mencaci maki dan merusak sejumlah barang-barang yang ada disana.

Peristiwa penyerangan oleh kelompok massa PDIP tersebut merupakan ancaman terhadap kebebasan pers dan/atau kemerdekaan pers nasional yang menunjukkan sikap anti-demokrasi. Perlindungan hukum terhadap kemerdekaan pers harus selalu dijaga dan ditegakkan, sehingga tidak menimbulkan preseden buruk dimasa yang akan datang bagi kebebasan pers. Segala macam bentuk intervensi baik menggunakan kekerasan maupun tidak menggunakan kekerasan sangat bertentangan dengan undang-undang pokok pers sebagai berikut Pasal 18 Ayat (1)," Setiap orang yang secara melawan hukum dengan sengaja melakukan tindakan yang berakibat menghambat atau menghalangi pelaksanaan ketentuan Pasal 4 Ayat (2) dan Ayat (3) dipidana paling lama 2 (dua) tahun atau dengan denda paling banyak Rp 500.000.000,(Lima ratus Juta Rupiah)".

25 Ramdhan Triyadi Bempah. (Kompas.com, 31/05/2018) "Minta Klarifikasi Berita Megawati, Ratusan Kader PDI-P Geruduk "Radar Bogor"'", dalam

https://regional.kompas.com/read/2018/05/31/123452 71/minta-klarifikasi-berita-megawati-ratusan-kaderpdi-p-geruduk-radar-bogor. diakses 20 November 2018.
Berdasarkan Surat Pernyataan Dewan Pers Nomor 1/P-DP/VI/2018 tentang Pemberitaan yang Berujung Penyerangan terhadap Kantor Redaksi Radar Bogor yang tertuang dalam poin ketiga yang berbunyi Terhadap dugaan adanya tindak pidana dalam kasus ini, Dewan Pers mengimbau aparat hukum yang berwenang untuk mengambil tindakan sepatutnya, demi tegaknya kemerdekaan pers. Keputusan tersebut sebagai bagian dari penegakkan hukum dan perlindungan hukum akan kebebasan den kemerdekaan pers nasional di indonesia sesuai amanat konstitusi dan ketentuan undang-undang pers. Perbuatan yang dilakukan oleh sekelompok massa PDIP bukan merupakan kewenangan dari Dewan Pers, sehingga rekomendasi dewan pers adalah berupa himbauan untuk lembaga yang berwenang untuk menyelesaikan perkara berdasarkan perundang-undangan.

Dalam proses penegakkan hukum terhadap dugaan intimidasi dan penyerangan pihak Kepolisian Republik Indonesia melalui Kepala Divisi Hubungan Masyarakat Markas Besar Kepolisian RI Inspektur Jenderal Setyo Wasisto mengatakan kasus penggerudukan kantor surat kabar Radar Bogor_oleh massa Partai Demokrasi Indonesia Perjuangan (PDIP) tidak mengandung unsur pidana. Selain itu, antara Radar Bogor dan PDIP sudah ada pertemuan serta kedua pihak sepakat untuk menyelesaikan masalah secara damai. $^{26}$

\footnotetext{
${ }^{26}$ Kukuh S. Wibowo. (nasional.tempo.co, 3/6/2018). Polri: Penggerudukan Radar Bogor oleh PDIP Tak Ada Masalah Pidana dalam https://nasional.tempo.co/read/1095071/polripenggerudukan-radar-bogor-oleh-pdip-tak-adamasalah-pidana diakses 20 November 2018.
} 
Keputusan dari pihak kepolisian menimbulkan gelombang penolakan dari komunitas pers di Indonesia. Banyak pihak menilai hal tersebut menciderai kebebasan pers dan tidak melindungi perangkatperangkat pers. Salah satunya adalah Lembaga Bantuan Hukum (LBH) Pers memberi pernyataan terkait masalah tersebut bahwa kekerasan dan pengrusakan kantor Radar Bogor merupakan salah satu tindak pidana kekerasan terhadap orang dan barang secara bersama-sama sebagaimana dalam Pasal 170 Ayat (1) KUHP dengan ancaman pidana penjara lima tahun enam bulan atau penganiayaan sebagaimana dalam Pasal 351 Ayat (1) KUHP dengan ancaman pidana penjara paling lama dua tahun delapan bulan. Sedangkan pengrusakan alatalat kantor merupakan bentuk dari tindak pidana pengrusakan sebagaimana Pasal 406 Ayat (1) dengan ancaman pidana penjara dua tahun delapan bulan. Ketiga Pasal di atas merupakan delik umum, sehingga pihak kepolisian bisa aktif melakukan proses hukum tanpa harus menunggu adanya pengaduan dari korban. ${ }^{27}$

Namun demikian, terlepas dari kontroversi dalam proses penegakkan hukum terhadap penyerangan dan/atau penggerudukan kantor Radar Bogor oleh sekelompok massa PDIP. Dalam kasus tersebut perlu juga melihat sudut pandang hukum pidana kontemporer dalam pemulihan korban sebagai salah satu langkah yang dapat menjadi landasan penyelesaian hukum. Pandangan hukum tersebut

27 Endi Ruhita. (newsinvestigasi86.com, 31/5/2018). LBH PERS Desak Kapolri Usut Tuntan Penyerangan Kantor Media Radar Bogor dalam http://newsinvestigasi86.com/2018/05/31/lbhpers-desak-kapolri-usut-tuntan-penyerangankantor-media-radar-bogor/ diakses 20 November 2018. sering disebut dengan istilah Restorative Justice, sering dipahami sebagai pendekatan penyelesaian perkara secara adil dengan menekankan pada pemulihan kembali pada keadaan semula dan bukan pembalasan. ${ }^{28}$

yonsep Restorative Justice Braithwaite dan Strang memberikan dua pengertian, yaitu : ${ }^{29}$

Pertama, keadilan
restoratif sebagai
konsep proses yaitu
mempertemukan para
pihak yang terlibat
dalam sebuah
kejahatan untuk
mengutarakan
penderitaan yang telah
mereka alami dan
menentukan apa yang
harus dilakukan untuk
memulihkan keadaan.
Kedua, keadilan
restoratif sebagai
konsep nilai, yakni
mengandung nilai-nilai
yang berbeda dari
keadilan biasa karena
menitikberatkan pada
pemulihan dan bukan
penghukuman.
Berdasarkan pada putusan

Dewan Pers melalui penyelesaian kasus pemberitaan yang melanggar kode etik jurnalistik, serta itikad baik dari kedua belah pihak untuk menyelesaikan persoalan secara damai memberikan peluang proses Restorative Justice sebagai salah satu landasan penyelesaian kasus penyerangan Radar Bogor oleh pihak kepolisian. Namun demikian, dampak

${ }^{28}$ Eddy O.S Hiariej, Prinsip-Prinsip Hukum Pidana, Ed. Revisi (Yogyakarta: Cahaya Atma Pustaka, 2016). hlm. 44.

${ }^{29}$ Ibid. hlm. 45 
dari kejadian penyerangan terhadap pers nasional seolah mematikan kebebasan pers nasional, seperti halnya upaya pembredelan yang tidak dibenarkan oleh ketentuan undangundang pokok pers. Oleh karena itu, penegakkan hukum secara berkeadilan dalam upaya intervensi terhadap pers menjadi bagian penting terhadap perlindungan hukum dalam menjaga kemerdekaan dan kebebasan pers nasional di Indonesia.

\section{E. PENUTUP}

Perlindungan hukum dalam
menjaga kemerdekaan pers yang
diperjuangkan oleh semua pihak didasarkan pada kebijakan hukum tentang pers yang telah ditetapkan dalam perundang-undangan. Diantara upayaupaya yang dapat dilakukan, antara lain dengan mengedepankan pandangan pada Social Responsbility Theory oleh segenap insan pers nasional, sehingga kehidupan pers nasional dapat terjaga dan terselenggara secara professional. Berlandaskan pada konsepsi tersebut diharapkan Media Pers mampu menyajikan berita-berita maupun peristiwa sehari-hari yang dapat dipercaya, lengkap, dan cerdas dalam konteks yang memberikannya makna dari sebuah pemberitaan.

Penegakkan Hukum terhadap perlindungan Pers nasional telah diatur dalam Undang-Undang Nomor 40 Tahun 1999 Tentang Pers bahwa intervensi terhadap media pers tidak dibenarkan secara hukum dan merupakan bagian dari perbuatan melawan hukum dalam undang-undang pers yang diatur dalam Pasal 18. Dengan demikian, setiap bentuk perbuatan intervensi dan/atau intimidasi terhadap penyelenggaraan pers nasional diancam hukuman pidana. Akan tetapi, dalam proses penyelesaian perkara tidak menutup kemungkinan menggunakan penyelesaian dengan pendekatan hukum lainnya, seperti Restorative Justice .

\section{DAFTAR PUSTAKA}

\section{Buku \& Jurnal :}

Arrasjid, Chainur. Dasar-Dasar Ilmu Hukum. Edisi 1. Jakarta: Sinar Grafika, 2006.

Fuady, Munir. Kosep Negara Demokrasi. Cet. Ke-1. Bandung: Refika Aditama, 2010.

Fuqoha, Fuqoha. "Perlindungan Hukum Terhadap Kesempatan Kerja Bagi Masyarakat Lokal Di Kota Cilegon." Jurnal Wawasan Yuridika 2, no. 2 (2018): 35-57.

Garner, Bryan A. Black's Law Dictionary. Edited by Bryan A. Garner. Eight. St. Paul: Thomson Business, 2004.

Hiariej, Eddy O.S. Prinsip-Prinsip Hukum Pidana. Ed. Revisi. Yogyakarta: Cahaya Atma Pustaka, 2016.

Kusumaningrat, Hikmat, and Purnama Kusumaningrat. Jurnalistik, Teori \& Praktik. Cetakan Ke. Bandung: Remaja Rosdakarya, 2014.

Manan, Bagir. Menjaga Kemerdekaan Pers Di Pusaran Hukum. Cet. Ke-4. Jakarta: Dewan Pers, 2014.

Mulyana, Aji. "Perlindungan Hukum Terhadap Perempuan Dan Anak Akibat Tindak Pidana Abortus Provocatus Criminalis." Jurnal Wawasan Yuridika 1, no. 2 (2017): 139-54.

Salim, and Erlies Septiana Nurbani. Penerapan Teori Hukum Pada Tesi Dan Disertasi. Cet. Ke-2. Jakarta: Raja Grafindo Persada, 2013.

Soekanto, Soerjono. Pengantar Penelitian Hukum. Cet. Ke-3. Jakarta: UI Press, 1986.

Soekanto, Soerjono, and Sri Mamudji. Penelitian Hukum Normatif. Jakarta: Rajawali Press, 2006.

Sumandiria, A.S. Haris. Jurnalistik Indonesia: Menulis Berita Dan Feature. Cet. Ke-5. Bandung: Remaja Rosdakarya, 2014.

Susanto, Edy, Mohammad Taufik Makarao, and Hamid Syamsudin. Hukum Pers Di 
Indonesia. Jakarta: Rineka Cipta, 2010.

\section{Perundang-Undangan :}

Kitab Undang-Undang Hukum Pidana

Undang-Undang No. 40 Tahun 1999 Tentang Pers

Peraturan Dewan Pers Nomor : 6/PeraturanDP/V/2008 Tentang

Pengesahan Surat Keputusan Dewan Pers Nomor 03/SKDP/III/2006 Tentang Kode Etik Jurnalistik (KEJ) Dewan Pers.

Surat Pernyataan Dewan Pers Nomor 1/PDP/VI/2018 tentang Pemberitaan yang Berujung Penyerangan terhadap Kantor Redaksi Radar Bogor.

\section{Website :}

Achmad Fardiansyah. (Oke News, 1 Juni 2018). IJTI : Penyerangan Massa PDIP Ke Kantor Radar Bogor Ancaman Kebebasan Pers. Dalam

https://news.okezone.com/read/2018/06/01/ 338/1905444/ijti-penyerangan-massa-pdipke-kantor-radar-bogor-ancaman-kebebasanpers diakses 20 November 2018.

Endi Ruhita. (newsinvestigasi86.com, 31/5/2018). LBH PERS Desak Kapolri Usut Tuntan Penyerangan Kantor Media Radar Bogor dalam http://newsinvestigasi86.com/2018/05/3 1/lbh-pers-desak-kapolri-usut-tuntanpenyerangan-kantor-media-radar-bogor/ diakses 20 November 2018.

Fajar Pratama. (Detik News, 6 Juni 2018). Dewan Pers Vonis Radar Bogor Langgar Etik, Sesalkan Aksi Massa PDIP. Dalam

https://news.detik.com/berita/d-

4055506/dewan-pers-vonis-radarbogor-langgar-etik-sesalkan-aksimassa-pdip diakses 20 November 2018.

Kukuh S. Wibowo. (nasional.tempo.co, 3/6/2018). Polri: Penggerudukan Radar Bogor oleh PDIP Tak Ada Masalah Pidana dalam https://nasional.tempo.co/read/109507 1/polri-penggerudukan-radar-bogor- oleh-pdip-tak-ada-masalah-pidana diakses 20 November 2018.

Radbogmin2. (radarbogor.id, 30 Mei 2018). Ongkang-ongkang Kaki Dapat Rp.112 Juta dalam http://www.radarbogor.id/2018/05/30/o ngkang-ongkang-kaki-dapat-rp112-juta/ diakses pada 20 November 2018.

Ramdhan Triyadi Bempah. (Kompas.com, 31/05/2018) "Minta Klarifikasi Berita Megawati, Ratusan Kader PDI-P Geruduk "Radar Bogor"'", dalam https://regional.kompas.com/read/2018/ 05/31/12345271/minta-klarifikasiberita-megawati-ratusan-kader-pdi-pgeruduk-radar-bogor. diakses 
